\title{
Gas Flaring and the Contours in the Mismanagement of Nigeria Niger-Delta Environment
}

\section{Groupson Paul Okechukwu}

Ikechukwu Ogeze Ukeje

\author{
Department of Political Science, Federal University Ndufu Alike Ikwo, Abakaliki, Ebonyi State, Nigeria
}

\author{
Doi:10.5901/mjss.2016.v7n5p263
}

\begin{abstract}
Though, oil is central to the current industrial development and economic activities, the rate of exploration and exploitation has not been fair to environmental health and social life. The study exposes the mismanagement of gas exploitation activities leading to flaring in the region with serious consequences on the economic, ecological and community (socio-cultural) sustainability. Paper adopted quantitative and qualitative methods in the analysis of data generated through primary and secondary sources. Using environmental pollution and environmental degradation theory, findings reveal that carbon monoxide level of ambient air exists in some villages, showing that emissions relating to flaring were high due to mismanagement leading to ecological damage and related diseases which portend serious effects on climate change, greenhouse gas emission and the attainment of sustainable development to the nation's economy. The study recommends the collecting of the gaseous fuel and energy for state utilization and income and for government to develop the will to manage the existing hurdles with good policies that promotes sustainable development in the energy sector.
\end{abstract}

Keywords: Pollution, Climate Change, Gas Flaring, Black Cloud, Global Warming, Mismanagement

\section{Introduction}

Nigeria is an oil producing state among the nations of OPEC, whose natural endowment had turned out to make her an energy power house in term of values and wealth, next to gold and diamond in worth. The sixth ( $\left.6^{\text {th }}\right)$ oil producing country in the world, whose wealth and riches had not march the desires and yearn aspirations of its citizens' wants and expectation due to some avalanche of problems that invariably is the attributes of a failed human capital and infrastructural development. According to the research investigation, oil production has been going on in Nigeria for more than over 62 years together with the flaring of natural gas, but its devastation all this while was never brought to the fore. Reasons being that the perpetrators and allies are being shield in a political hocus - pocus paradigm of politicking based on interest. Understanding why this unsustainable practice has lasted for such a long time in the country entails the unraveling of the dynamics of the political influence of the multinational corporations over natural resources management in developing countries like Nigeria, (Chijoke, 2002:1).

Acceptably, Nigeria is endowed with quite a number of natural and human resources. Some of the key resources found in the Nigerian environment (soil) are limestone, bauxite, bronze, oil and gas, copper, natural forest and resources such as wild life amongst others. Unfortunately, among these enormous resources, only crude oil is being harness over the years. There are also a lot of petroleum products being derived from the crude, amongst, which are the premier motor spirit (P.M.S) the diesel (Agro), kerosene (DPK) low poor fuel oil (Lpfo) high poor fuel oil (Hpfo) amongst others. Gas resources in the same vein has been in its large quantity of over 40trillion cubic feet as Nigerian reserves, begging for exploitation and proper utilization for a more sustainable socio-economic development. Its existing quantity had also caused gas flaring over the years with the attendant effect on the immediate environment where the resources are located (Niger Delta). It is estimated to cost Nigeria US\$2.5 billion annually whilst the roaring, toxic flares affect the health and livelihood of Delta inhabitants. It is estimated that $66 \%$ of Nigerians live below the poverty line, to which some may be contented with it due to consistent neglect and marginalization. Gas Flare contributes significantly to climate change, thus affecting communities all over the world. With Nigeria per capita GNP lower than at independence, there is an appalling waste of resources that the country cannot afford.

Imperative on these highlighted issues, the study utilizes quantitative and qualitative method of analysis in tackling the identified problems while evaluating at the same time the logics behind the imports of politicking in the treatment of the issue of gas flaring and its consequences on the people of Niger-Delta. In this respect, the study employed a methodology that includes the study location and sites, the study population, the sample and sampling procedures of the 
investigation. Meaning that, in depth - interview method and analysis, which is the instrument of the investigation is greatly employed for easy comprehension and data interpretations. Based on this, the study unequivocally tends to unearth with facts an inspiring and hidden knowledge that had helped to plague the region's continual development prospect and constitute impediment with a possible panacea for the attainment of rapid sustainable ecological, economic and socio-cultural development in the economy. This paper addresses three questions: what is the politics involved in the management of gas exploration and exploitation in the Niger Delta, how has this impacted to the development of the region and what needs to change about the management of gas resource in the region?

\section{Niger-Delta, Synoptic History of Oil and Gas Flaring}

The area called the Niger Delta, which was formerly known as the Oil Rivers or the British Oil Rivers protectorate, with about $70,000 \mathrm{~km}^{2}$ and makes up $7.5 \%$ of Nigeria's land mass is today made up of Abia state, Akwa-lbom state, Cross River state, Edo state, Imo state, Delta state, Rivers state, Ondo state and Bayelsa state due to government new legislation in 2000 (Wilmolt, 2012). The area also house over 40 ethnic groups including the Efik, Ibibio, Annang, Oron, ljaw, Itsekiri, Igbo, Isoko, Urhobo, Ilaje, Yoruba and the Kalabari amongst others.

In Nigeria, with the discovery of oil at Olobiri in the oil Rivers in the late 1950s and as development and exploration of crude expands, the oil net of Nigeria that happens to be the biggest producer of petroleum in Black Africa, also increased with over 2 million $\left(320,000 \mathrm{~m}^{3}\right) \mathrm{bpd}$; so also the environmental problems and human devastations were on the increase due to poor exploratory and exploitation practices. Although, the actual operations, which includes the exploration of the crude and other minerals was undertaken by multinational corporation (like Royal Dutch Shell and Shell BP, Agip, Chevron, Conoco, Slumberg, Total and Texaco among others) who in turn helped in providing the Nigerian state with necessary technology and financial resources, the necessary side effect of this overture has a long term problematic consequences even though it was ignored; probably willfully or by sheer negligence as it was not long as expected before the causal effects appeared. With the internationalization of oil business and the concomitant drive for oil wealth by both friends and foes of Nigeria with the connivance of the elites, devastation, pollution, ecocide, kleptocracy, gas flaring, environmental degradation and human rights abuses became evident.

Thus, partly agreeing that despite the country's huge economic gains from oil, that one naivety that had confronted the whole situation was the issue of "do not mind the devastating effect of oil exploration, what should be prime and of interest is the wealth and turnover". A crude idea of human existence in a capitalist society where life and destruction means nothing compared to value and gains of profit. Meaning that the issue of gas flaring is not what government can waste resources in tackling headlong. But instead, what might have played out the rhythm are the political intrigues that both the government and their international partners - the multinational corporations, seems to import, impose and display concerning the health hazard to which its general implication goes with the detriment of the communities thereby, hampering sustainable development in the region. In support of this notion according to http://www.wikipedia.com (2012:2-3) the superfluous quantity of oil, together with gas extraction comprising of over $97 \%$ of Nigeria's foreign exchange revenue was what the parties were concerned of. This is because much of the natural gas extracted in oil wells in the Delta is immediately burned or flared, thereby causing over 70 million $\mathrm{m}^{3}$ per day. The equivalent being $41 \%$ of the total African gas consumption, and which also formed the largest single source of greenhouse gas emission on the planet earth. An internationalized consequence, which implies that climate change devastation, could be imminent in the Delta region and the sub-Saharan Africa in general.

\section{Theoretical Arguments}

Mindful of the level of devastations, dislocation and distortions in the Niger Delta owing to the effects of gas flaring and oil exploration, this study adopts the theories of Environmental Pollution and Environmental Degradation. The linkage of the two was meant to provide a strong research base to enhancing the inquiry vis-à-vis in bringing the activities in the Niger Delta to the fore.

\section{Theory of Environmental Pollution}

Inference on the problems of gas flaring in the Nigeria - Niger Delta environment, especially environmental pollution, which comprises of the air, water and land pollutions, this study adopts the theory of environmental pollution. Some scholars of this school like Heltland Gloria E. (2010), Bobak, M. Leon (1999), Peter Maull Tim (2010), Pietro P. (2011) and Rachel Carson (1962) among others argued that pollution, which is destructive and hazardous to the environment 
and people are due to ambient air pollution that has a great effects on health, economy, human productivity and ecological sustainability.

According to Encyclopedia Britainica (2002), the general principle that pollution (air), especially from gas flaring, occurs all the time, all day and has a consequential damaging effects on the people is there. It emits CO2 into the atmosphere to causing havoc on lives and living organisms. In support of this notion, Mittermeier (2012) observed that pollution occurs when the ecosystem are not safeguarded and are tenaciously exerted with forces greater than the capacity it can absorb. In the words of Mario (2003), Claudia (2002) and, Brunekreef and Holgate (2002), pollution reduce the prestige of people either in organization, occupation or environment. The ambient air pollution and socioeconomic position impact a great deal on the health of the people and society. The ambient air pollution like gas flaring also has a link to health effects, which include mortality and morbidity from heart and lung diseases, impaired lung function and lung cancer. Implicit on these analogies, is the evidence that gas flaring causes air pollution.

\section{Theory of Environmental Degradation}

According to the scholars of this school, like Meyers R. (1985) Jack D. Ives (1987), Cameron Truddy Ann (2006) G.M.P. de Silva (1991) and Steven Shavell (2010) among others, environmental degradation create a huge loses to the economy and it is link to other problems that denied the environment the natural gifts that ought to benefit man. Agreeing to this notion, De Silva (1991) aptly noted that apart from destruction of forested areas, wetlands, grasslands and bodies of water, environmental degradation could be increase when the people presses for fuel, fodder, water, land cultivation and or explorations for natural resources. This kind of exploitation on the environment for resources to sustain livelihood helps to add to the societal woos.

Thus, the stated theories above explains the correlationship between theory of pollution and theory of environmental degradations as affecting the Niger Delta communities and people. The level of damages to the ecological and socio-cultural sustainability of the local communities, leaves them at the mercy of terminal diseases and death.

\section{Methodology}

Against the large areas affected by the menace of gas flaring in the region, the study utilizes and adopted random sampling technique in selecting the localities for the investigation. To aid the fieldwork, questionnaires was administered to some key informants while oral face to face interview methods was greatly used in sourcing for information amongst the selected communities of: Ebocha - Egbema, Oboma, Rumuekpe, Patani, Bomadi and Okpoloma among others, which formed the study locations and sites. The sample populations are the men, women and even non-indigenes to these communities. Imperative on the inquiry, data were collected and analyzed with the aid of Chi-Square analysis to testing for both null and alternate hypotheses. The usage of both primary and secondary data in this study was not only to enhance scholarly work but to ascertain the originality and true state of events in the Niger-Delta vis-à-vis the level of damages of gas flaring. To enhance the qualities of the work the study also adopts perceptive study that is, getting to know how the dwellers or the people in the Niger Delta communities perceive gas flare in the area. In knowing how the people feel about gas flare in the study area, a few unstructured questions were posed to them in order to get the perceptions of dwellers about the hazard. Seven questions were used in the selected communities, so as to get the necessary information needed for the work.

The questions were designed to accommodate personal information of persons, which was never a barrier nor was it taken into cognizance in the course of analysis as they were all victims of the same gas flaring. The questions also contained those designed to getting the causes of gas flaring in the Niger Delta. While there was also some sets of questions designed to get the impact, effect and problems created by gas flaring amongst the people and communities and the possibility of how to control its menace, since gas flaring itself is an artificial phenomenon which occurs in the Niger Delta.

\subsection{Data Presentation and Analysis}

The followings represents the data collected and its subsequence analysis, based on the posed questions of: Is gas flaring an environmental friendly? Does it boost the health condition of the people? Is it economically advantageous to means of livelihood? Does it have any negative effect on the communities experiencing it? Does gas flaring have human factor or artificial factor? Is it prone to unhealthy living? Does government cum agents or oil firms have stake in gas flaring hazards on the people? What is the probability that government cum oil firms are not benefiting from the wastage of gas flaring. 
Table 1: Distribution of Population by Sex

\begin{tabular}{|l|c|c|c|c|cc|c|c|}
\hline Distribution & A & B & C & D & E & F & Total & $\%$ \\
\hline Male & 9 & 7 & 6 & 6 & 7 & 5 & 40 & 57.2 \\
\hline Female & 6 & 5 & 6 & 5 & 4 & 4 & 30 & 42.8 \\
\hline Total & 15 & 12 & 12 & 11 & 11 & 9 & 70 & 100 \\
\hline
\end{tabular}

Source: Fieldwork, October 2015.

Where the alphabets in the table above represents the name of the sites as follows: $A=$ Ebocha-Egbema, $B=$ Oboma, $C$ $=$ Rumuekpe, $\mathrm{D}=$ Patani, $\mathrm{E}=$ Bomadi and $\mathrm{F}=$ Okpoloma. In general observation, it is noted that of the people interviewed as above, that $57.2 \%$ (40) are male while $42.8 \%$ (30) are female as seen in the data above. From Table 1, above, this shows the distribution of response per sex and the total number thereof. It is clear that majority of those interviewed in the course of the inquiry are male population from Ebocha-Egbema (9), Bomadi (7) and Oboma (7). While Rumuekpe (6) and Patani (6) have equal number of key informants. It is only Okpoloma (5) that have less respondents amongst the interviewed informants. Sequel to the posed questions above, the responses obtained was grouped into a chi-square analysis in table 2 below according to the responses from individual communities for simplicity and easy comprehension since the selected communities are victims of the same hazard - gas flaring.

In view of the above posed questions and many others, the key informants were grouped into both male and female as a way of having a general overview of the response of each community affected by the incidence of gas flaring. In table 1, above, there is great difference between the male respondent and their female counterpart as $57.2 \%$ of men to $42.8 \%$ of the female at Ebocha-Egbema, Oboma, Rumuekpe, Patani, Bomadi and Okpoloma Communities indicate that the men are reactive and vocal in their condemnation of the menace of gas flaring in their communities than the women. It also proved that the men have more say in the community than the women who seemed to be more concerned on family and domestic front than the menace plaguing them. This does not mean that they are in any way in support of the devious act of gas flaring in the area. The investigation noted that both sex however were out to express their displeasure over the dislocation of their community by the menace of gas flaring. Respondents were aware of the consequence and the environmental effects on lives and livelihood and were in no way ready to compromise their rights.

Being keenly aware of the destruction of their environment, which probably might have informed the inciting of the youth of the area to indulge in seizing or kidnapping some staff of the oil workers unless compensation and better deal are agreed upon by all the parties, since their environment is not habitable as skin disease, cough and other terminal diseases had infested the community. The community lives in water that is highly polluted. The corrosion of wrings on the water surface and the dead of plant and vegetation explain the kind of live observed in the coastal line where gas flaring, oil spillage and environmental degradation had placed many of the host communities in the Niger Delta in a state of mercy and pity of visitors. However, in the final collation, the study had a cumulative total percentage of $57.2 \%$ for the male over $42.8 \%$ for the female. This calculation still informed from the separate individual community response to the cumulative $\%$ that the male are more aware and are at the same time in the forefront of the struggle against the menace of gas flaring that had invariably devastated their communities in the coastal line of the Niger Delta. In the investigation, the $100 \%$ sum in the addition to each community responses shows the coherence and strength of the people in realizing the menace of gas flaring on environmental sustainability, while at the same time speaking out to the international human rights group, Amnesty International and the International community to visit and conduct survey on what they had been complaining about of the level of destruction and neglect of the Niger Delta host communities by both the oil companies and the Nigeria government. The investigation also revealed that there are indeed gas flaring hazard in Niger Delta host communities like Ebocha-Egbema, Oboma, Rumuekpe, Patani, Bomadi and Okpoloma communities of Niger Delta coastal line.

\section{The Effects of Gas Flaring}

\subsection{On health of the people of Niger Delta}

The study in a general collation had about 40 by 30 persons of $57.2 \%$ and $42.8 \%$ key informants interviewed, spreading the six communities with imbalance being the error incurred in the process of collection. This means that the effect of gas flare on the people is still at its lower degree but has the tendency to grow to the level of seriousness if not checked and controlled. Taking cognizance that all the communities are directly affected with one measure of high, serious health 
problem or another it is imperative to point out that the general health condition of the people are under a serious threat. Gas flaring increases the risk of respiratory illnesses, asthma, impaired lung function and cancer (Brunekreef and Holgate, 2002, and Ige, 2007) and reduction in lives expectancy, birth outcome and perpetual black cloud in the environment (Maull and Berck, 2010).

\subsection{Farms/Farming}

The general effect of gas flaring on farms and farming processes was also noted. The farms and farming projects were highly affected by the hazard of gas flaring. The general implication shows that economic trees, crops and plants and cultivable lands are greatly damaged. Thus, Okene (2008) in seeing the havoc caused by gas flaring at Ebocha-Egbema detested the degree of gas been flares into the air. He averred how a stump of what was once a coconut tree met its untimely death owing to the menace of gas flaring in the area. This degree of plant and animal farms destruction in the community indicates that the hazard of gas flare in the studied communities informed of the awful damage on the Niger Delta. The research observed at Bomadi and Patani communities that most animals like goat, grasscutter, sheep, poultry and birds are seriously infected by virus and some inhaled diseases. Some animals like goat, sheep and cow amongst others, consumed plants infected by gas flaring-borne-diseases and died. Noticeable also among some of the animals are dwarf or stunt growth.

\subsection{Fish/ Fishing and Aqua-Life}

The people of the Niger Delta coastal line are renowned for their fishing and aquatic life exploits, but the robust business for which they are known for many years had been cut short by the incidence of gas flaring. The effect is shown to be high at Okpoloma community with 22\%. Meaning that fishing, which is their only means of livelihood had been greatly affected by the pollutant from gas flaring which invariably kills the fishes and other aquatic life in the rivers and streams in the community. The same impact was noticed at Patani community with 18.2\%; Oboma and Rumuekpe communities $17 \%$ each; and Ebocha-Egbema - 13\% showing that there is similarity in the effect as most fishing water is poisoned by the $\mathrm{CO}_{2}$ emissions from the gas flaring effects. Thereby, affecting fishermen and fishing activities in the communities. With the acidic content of most waters in the investigated communities, their means of existence, fishing had been greatly destroyed by the colour and cloudy black look of the most water in these communities. Thus, the ecosystems in this investigated communities had shown that blackish swamp forests, water changing to charcoal-black slippery to kill aquatic lives like fish and others becomes the attendant phenomena in almost all the Niger Delta coastal lines. This water contamination affects the fish population and affects the fishermen that rely on fishing to support their family (Osita, 2008).

\subsection{Air/Water Pollution}

The activities of gas flaring also cause air or water pollution. The effects of this on both water and air also helped to increase the degree of havoc on the environment and human lives. Hence, Omeje (2006) asserts that despite the substantial revenue from oil production, Nigerian continues to suffer from environmental degradation associated to gas flaring that had continued to be norm in the Niger Delta region. This might be probably because Nigeria is the second largest gas flared in the world. In the word of Okonta and Oronto (2003), the rate of gas flaring in Niger Delta and emissions contributes significantly to global warming, which composed of toxic gases such as sulfur oxide $\left(\mathrm{SO}^{2}\right)$, nitrogen oxide $\left(\mathrm{NO}^{2}\right)$, benzapryene, toluene, xylene and hydrogen sulfide $\left(\mathrm{HSO}^{2}\right)$ amongst others have negative effect on the environment and people.

In the foregoing, it is evidence that air or water pollution in Niger Delta are more prevalent because of the activities of oil firms and oil production which had invariably encouraged and promote gas flaring. Gas flaring has a great harmful effect on health, farming, fishing, and aquatic lives in the Niger Delta. This investigation might be quick to affirm that the problem of gas flaring in the Nigeria - Niger Delta as haven been more of human factor than artificial factor, since there were several legislation, both national and international laws banning and disapproving the act of flaring an associated gas. Therefore, using table 2 below, the study will further test on this problematic underpin of Human and Artificial factors sentiments in finding out the causes of gas flaring in the Niger Delta. 
Table 2:

\begin{tabular}{|l|c|c|c|c|c|c|c|}
\hline Letter & A & B & C & D & E & F & TOTAL \\
\hline Causes & 9 & 7 & 6 & 6 & 7 & 5 & 40 \\
\hline Human Factor & 9 & 5 & 6 & 5 & 4 & 4 & 30 \\
\hline Artificial Factor & 6 & 12 & 12 & 11 & 11 & 9 & 70 \\
\hline Total & 15 & 12 &
\end{tabular}

Source: field survey, October 2015.

Using the Chi-square analysis in view of the problem raised above while trying to reviewed the people's perceptions where the Chi-square formula is: $X^{2}=\frac{(O-e)^{2}}{e}$

Where

$0=$ Observed figure

$\mathrm{E}=$ Expected figure

$C=$ Column total

$r=$ Row total

\begin{tabular}{|c|c|c|c|c|}
\hline S/N & O & E-O & $(\mathbf{O}-\mathrm{E})^{2}$ & $\frac{(\mathbf{O}-\mathrm{E})^{2}}{E}$ \\
\hline a. & 9 & 8.57 & 0.19 & 0.02 \\
b. & 7 & 6.86 & 0.02 & 0.00 \\
c. & 6 & 6.86 & 0.74 & 0.12 \\
d. & 6 & 6.29 & 0.08 & 0.01 \\
e. & 7 & 6.29 & 0.05 & 0.08 \\
f. & 5 & 5.14 & 0.02 & 0.00 \\
g. & 6 & 6.43 & 0.19 & 0.03 \\
h. & 5 & 5.14 & 0.02 & 0.00 \\
i. & 6 & 5.14 & 0.74 & 0.14 \\
j. & 5 & 4.71 & 0.08 & 0.02 \\
k. & 4 & 4.71 & 0.50 & 0.11 \\
I & 4 & 3.86 & 0.02 & 0.01 \\
\hline
\end{tabular}

Given the critical value $(\mathrm{CV})$ at 0.50 significance level to be 3.84 . The degree of freedom

$=(r-1)(c-1)=(6-1)(2-1)=5$

Therefore: if , $X^{2}=0.54$

$$
\begin{aligned}
& \mathrm{CV}=3.84 \\
& \text { Interpretation, then }=\mathrm{X}^{2}<\mathrm{CV} \\
& \text { That is } 0.54<3.84 \\
& \text { Where, } \mathrm{HO}=\mathrm{Hi}
\end{aligned}
$$

And since critical value is greater than the $X^{2}$, it means that $C V>X^{2}$, then we accept null hypothesis $(\mathrm{Ho})$ and reject the alternative hypothesis $(\mathrm{Hi})$. This interpretation then suggest that the problem of gas flaring and environmental degradation in the Niger Delta region is more artificial factor than human factor. Then, also there are significance differences between the responses, because the views varies to certain degree while still pointing to one directions that the enabling laws were willfully disregarded, violated and abandoned by both the oil firms and their government allies, thereby leaving the people of the area to die in their predicaments. This level of politicking also informs that there are some community leaders who convince with the government and oil companies to distort and dislocate the vulnerable members of the community. The element of insincerity in treating gas flaring default despite its negative implication then forms the basis of this endeavour to certain level. 


\subsection{What needs to change in Niger Delta: The Unforgettable Roles of Nigeria and the Multinational Firms}

Based on the findings of this study and agreeing that gas flaring is real in Nigeria-Niger delta by virtue of being an oil producing states with over 180 billion cubic feet of natural gas; and agreeing also that the act of disposing of waste gases through combustion in Nigeria has been at a high magnitude for a long time since the inception of oil exploration without any solution in sight; it is obvious that gas flaring had combined with environmental degradation caused by oil spillage, land slide and other natural disasters to cause untold hardships on the people of the localities of the Niger Delta. The basic questions that then strike the mind toward unraveling this evil acts are: Does government exist at all in Nigeria? If yes, are there legislations as regarding the monitoring and controlling of the activities of the MNCs in term of oil exploitation and environmental distortions? Who manages oil exploration in Nigeria? Is it the Nigerian state or the MNCs? What are the stakes of the host communities' vis-à-vis oil exploration benefits, developments and the consequential effects on the communities?

Considering the above raised questions, and whether gas flaring is normal in any oil producing environment, Nwauche (2010) and Chijoke (2002) argued that it is a common practice in the oil production process, but the Nigerian case attracts more attention given the volume of gas flared since the beginning of commercial oil production in the country. This, they further argued in comparison, that social responsibility attitude towards gas conservation in Nigeria and Canada are different, because the demand partly due to environmental requirements in Canada and other advanced countries does not apply in Nigeria. The point of emphases here is that the Nigerian government legislation seems to be weak towards monitoring and controlling the activities of the MNCs as each operates on different sphere while play the hocus-pocus paradigm of relying on the existing laws. A political intrigue that played itself against the cry and protest of the people of the communities on the hazardous effects of flared gas was seen in the proposed legislation on the menace of gas flaring. A bill was proposed by a private person on how to checkmate the nefarious activities of the oil companies, but it was blocked by government agents who benefit from the oil companies in the year 2000. According to Chijoke (2002), Oranto (2003), Okereke (2007), Ukala (2011) and Omeje (2010), in this respect, the weakness in the government-push to reduce the excesses of gas flaring makes it to yield no result as nothing is happening toward solving the endemic of gas flaring. Chijoke (2002) specifically revealed that even oil producing companies in the country jointly attacked the proposed policy legislation as "technically infeasible". The companies argued that accelerating the flare programme is unrealistic because it is a national policy and not private, requires huge investment for the acquisition of the needed technologies, has technicalities to be considered and hence must not be done in a hurry.

In effect and following the pressure of the oil companies, Chijoke (2002) revealed, that the federal government of Nigeria rescinded its initial 2003 deadline and extended it to 2008 which till this day have not seen the light of the day as there was no change in their activities till date. The question, which many still ask based on the federal government compromise on the above issues, and which goes in line with the questions of who manages oil exploration in the country, is how committed are these companies towards attaining terminal flare in the years to come since they had shown reluctance to accomplish a genuine policy on gas flaring? According to Oronto and Okonta (2003) the Nigeria government is probably interested in what it is gaining from the oil firms through its agents, is misinformed and at same time not committed to solving the problem of gas flaring.

The failure of Nigeria government in asserting its strength to control and reduce gas flaring may likewise agree with Chijoke (2003) and Kalu (2006), who also noted that the federal government by acting on the dictates of the oil companies shows that it had relegated the health, life span and environment of many well-being Nigerians to the background. The idea of accommodating the oil companies at all cost and by all means in the country bears outrageous cost and economic dislocation of misplaced priority as a government. It is a dangerous trade-off between economic gains on one hand and public and environmental good on the other, which have long term consequences that are highly destructive. In addition to the pretentious act of the government, Kalu (2006) observed that the fears of the unknown and probably economic lost are what the government is afraid of experiencing, thus, submitting to the whims and caprices of these international oil agents. The lukewarm attitude on the side of the government that ought to regulate and supervise the oil sector to cleanse the problematic and harmful side of the business and all the necessary businesses under it among others portrayed the weakness of a house owner to a house cleaner relationship. Where the latter chooses the area of the house where it will work on and the area it will not and the master accepts because of the fear of losing its services and the unknown that might await the home. The essence of the government to monitor and control all the oil business includes to create a healthy and conducive atmosphere to all players and stake holders, but when the opposite become what the people are seeing at Ebocha - Egbema, Obioma, Patani, Okpoloma, Rumuekpe and Bomadi among others, then the issue of "do we have any government in Nigeria" becomes the reasonable questions on the lips of both the victims and the onlookers. Evidence available according to Ted Case Studies (1998) showed that the above 
mentioned communities have been severely damaged by environmental pollution from oil spills, dumping of waste products, burning of excess gases, pipe-line leaks, oil well blowout, gas flaring operations and widespread ecological disturbances. According to the report it is this same problem that prompted the face-off between Ogoni people and the oil firms, especially the shell BP. It further argued that the federal government had consistently connived with shell petroleum to damage the local environment as seen above, by operating a number of off-shore rigs and oil port facilities which have seriously damaged the mentioned communities, especially those located at the tropical rain forest in the Northern reaches of the Niger Delta and the mangrove vegetation of the South. These long-based economic gains did not only form the basis of the degree of grandstanding politicking in matters concerning the region but has also continued its avoidable neglect and devastation.

Based on the analogy so far enunciated, it is obvious and factual that the Nigerian government against whom it would be loses for acting to protect her citizens from the menace of the MNC operating oil exploration in the Niger Delta, had swallowed its pride to politicize every angles of oil business in the Niger Delta, and with gas flaring being inclusive. It is also clear that for long, that the Nigerian government had been indicted for failing in its responsibilities, hence, the current issue of gas flaring, which is ominously devastating to the case study communities. Others had reaffirmed the truth that since the early seventies up to the new millennium, the Nigerian governments had failed in enacting and enforcing environmental protection laws against oil damages, gas flaring and other hazardous impediments to the people of Niger Delta. If not so, why is any protest against such devastation and destruction of oil spillage, consistent and uncontrolled gas flaring always termed a threat to oil facilities and economic sabotage by the government and its partners, MNCs? However, the political instruments used by the governments to silence protesters are coercive instrument of the state, divide and rule, genocide, subjugation and diplomacy. The social and environmental cost of this incident is politically seen as cheap blackmail against the government of the day in responding to protest and complains. It is this level of politicking and wishful neglect that had resulted in the high incident of wildlife and biodiversity destruction, loss of fertile lands, pollutions, asthma, bronchitis, cancer and several other epidemics noticeably ravaging the people of Niger Delta.

Curbing flared gas as seen at Patani, Bomadi, Okpoloma, Rumuekepe, Ebocha-Egbema and Obioma communities among others could substantially offer oil field operators significant safety and so many economic and environmental advantages to other stakeholders, which include; reduction in green house emission, enhanced economic growth, stability, job creation and attraction of foreign investments for enhanced sustainable development in the region.

\section{Conclusion and Suggestions}

This paper has inquired into the mismanagement of gas resources in Nigeria Niger Delta. Evidence from the study shows politicization of gas exploration and exploitation activities thereby aggravating tensions and provocations of aggressiveness at any slightest disagreement due to the devastation of host-communities environments, sources of livelihood and health. Against environmental and health problems in the region, the government, organized private sector, and most stakeholders in the oil and gas industry with the aid of their foreign counterparts have not cooperatively measured up to expectation. There is still lack of will to having a joint bond to making more effort in the promotion of even utilization of liquefied natural gas in factories, medium scale industries among others that could lead to the optimum stoppage of gas flaring in Nigeria.

Thus, the establishment of a liquefied natural gas plant at Bonny in Rivers State by the federal government of Nigeria and the MNCs operating in the country in order to promote the export of natural gas, utilize and discourage zero gas flaring is welcome. However, lapses, inconsistency and delay should be checked so that the plant can adequately be utilized. If this is properly attended to and the wasted gases duly collected, the Nigerian economy might be strengthened, thereby promoting the three principle of alternative routes to utilization of gas resources, in terms that the gas can be reinjected into the reservoir to maintain pressure and enhanced oil recovery (EOR) or stored in underground formations; used for energy purposes on the production facility or nearby facilities or collected, cleaned and sold.

To reduce this practice also, the government needs to develop and enforce an appropriate legal and regulatory framework such as the current Petroleum Industry Bill (PIB) before the National Assembly, reform the gas market, avoid tax and royalty systems that discourage operators from using the gas associated with oil production and implement social safety programmes to cushion the effect of the present hike in petroleum products on citizens. In the same process, the government and the oil companies should remove all barriers and attend to the problems of the host communities like implementing the UNEP report on Ogoni land that had been greatly affected by the oil business so as to encourage economic, ecological and community sustainability. 


\section{References}

Brunekreef, B. and Holgate, ST. 2002 Air Pollution and Health Lancet 360:1233 - 1242.

Brunekreef, B. Janssen NA De Hartog J, Harssema H, Knape M, Van Vliet P. 1997 Air Pollution from truck traffic and Lung function in children. Epidemiology 8:298 - 303.

Claudia, G. 2002, A Pollution Theory of Discrimination: male and female Differences in occupations and Earnings NBER working paper No: 8985. Issued in June.

Ige, A.C. 2007, "Ebocha-Egbema General Hospital and the Furiousness About Gas Flaring" in NPR.

Kalu, O.A. 2006, Gas Flaring and Air Pollution over the people of Niger Delta. APA Newsletter

Marie, S.O. Jerrett, M. Cohen, J.A. 2003, Health, Wealth and Air Pollution: Advancing Theory and Methods. U.S.A. Environ Health Prospects.

Meyers, N. 1985, The theory of Land Degradation: The Gaia Atlas of Planet Management. London: Gaia book Ltd.

Mittermeier, C. 2012, Ecosystem and the protection of nature properties, London: CI Press.

Okene, E.K. 2008, "The Hazard of Gas flaring in Niger Delta Communities" in NPR

Okereke, J.N. 2007, Microbial Flora of Oil-spilled sites in Egbema, Imo State, in Nigeria Academic Journal Retrieved Feb. 2012.

Okonta, I. and Douglas, O. 2003, Where vultures feast: Shell, human rights, and oil in the Niger Delta. Sierra Club Books, San Francisco. 267 pp.

Omeje, K. 2006, High Stakes and Stakeholders Oil Conflict and Security in Nigeria. Port Harcourt, Rivers State.

Osita, C. E. 2010, "Global Warming: An Overview and Implication for Nigeria" in Osita C.Eze and Ogaba Oche (ed) Climate Change and Human Security in Nigeria. Nigeria Institute of International Affairs, Lagos: printServe Itd. 2002, "People and the environment annual report" in SPDC (the Shell Petroleum Development Company of Nigeria Limited) Report.

2008, "Gas flaring continues to Plague Nigeria" Encyclopedia, Retrieved Feb. 2012.

2006, "Niger Delta Human Development Report" in UNDP Retrieved Feb. 2012.

2009, See Amnesty International Nigeria: Petroleum Pollution and Poverty in the Niger Delta UK Amnesty International Pub. 1999, "Niger Delta Archives of News, Interviews, Articles, Analysis from 1999 to the present" in UNDP Niger Delta Human Development Report.

2003, Urhobo Historical Society: Urhobo Historical Society Respond to Itsekiri of Western Warri city. August $4^{\text {th }}$. 1997, Ted case studies: Ogoni and Oil: Nigerian Petroleum Pollution in Ogoni Region.

-2012, "Theories of Pollution and Impurity" Encyclopedia Britanica. June Retrieved July 2012.

Ukala, E. 2011, "Gas glaring in Nigeria's Niger Delta: failed promises and Reviving community voices" climate change and Environmental law seminar Lee University Law School Washington.

Wilmolt, H.C. 2012, The Doubting Policies of Nigerian Government Sincerity on Handling Gas Flaring. Oron: Essan and Effiong pub. 